\title{
クワインの行動主義
}

\section{古田智 久}

クワインは，一般に行動主義者と考えられる傾向にある。このことは，彼が 根源的翻訳という思考実験を展開する際に用いる道具立てが刺激一反応という 行動主義の図式であることや，客観的に査定可能な言語というものを〈非言語 的な刺激に対して言語的に反応する傾向性の総体〉というように捉えているこ と，あるいは，言語学習の初期のプロセスを説明する際にスキナーの方法を踏 襲していることなどに起因するとみてよいであろう。しかしながら，その方法 論の類以性のみを根拠として，両者の主張の同一性を導いてよいものであろう か. 本論文の目的は，クワインの行動主義の具体的内容を特定し，彼が，我々 の心的活動，その中でも特に言語活動に対していかなるアプローチが可能と考 えているかを示すことである. 本論文では，行動主義の有力な批判者であるチ ヨムスキーによるクワイン批判及びそれに対するクワインの返答を検討するこ とによって，クワインの考え方を理解するという戦略がとられる.このような 論述を経て，クワインの行動主義が，心的状態や心的出来事を観察可能な行動 によって説明し尽くすことを目指す強い行動主義ではなく，単に「メンタリス ティックな概念を客観的に理解する一つの方法」(1) を採用するものにすぎない ことが指摘される.

\section{1 チョムスキーとの論争}

チョムスキーが行動主義を批判する最大の理由は，〈刺激一反応という外的 要因のみに基づくアプローチによっては，人間の心が関与する諸事象がもつ創 造的側面を説明することができない〉ということである．彼は，この難問を解 
決するために，合理主義的な構想の下に議論を展開した.

チョムスキー自身も, 行動主義者と同様, 彼らが熱中する行動の研究に意義 を認めている(2) . 彼によると, 行動の研究の目標は, 一定の経験を経た有機体 がある刺激状態に直面した場合に，その有機体がとる行動を決定するようなメ カニズムを探究することである(3). しかしながら, 従来の心理学における行動 主義的研究は, 経験 [外的刺激]と行動との関係を直接結びつけるという方法 をとっており，このような方法が不毛であることは既に明らかである，という のは，非常に複雑な認知構造を有する人間の言語活動に関しては，外的刺激の みによる予測がほとんど不可能だからである，チョムスキーは，状況に対して は適切でありながら刺激によっては統制されえない行動が非常に多くあると考 えて，行動主義の枠組の適用範囲の狭さを指摘した。この点にチョムスキーの 行動主義批判の核心がある. 彼は，有機体の行動の原因を研究する際には，ま ず(1)様々な経験から一定の認知状態(cognitive state) を形成する学習理論を構 築し，次に(2)一定の認知状態に達した有機体が何らかの刺激条件を行動に関連 ゔけるメカニズムを研究する，という手順を踏まなければならないと考える(4). 行動主義の研究方法はこのような認知状態という媒介項を設定するものではな いため，チョムスキーは心理学におけるそのようなアプローチを拒否するので ある。

ところで，チョムスキーにとっては，学習理論とは，一定の認知構造が経験 に基づいてどのように獲得されるかを説明するものである(5). 正常な子供であ れば誰でも，比較的わずかな期間言語的環境に接するだけで，複雑な構造をも つ言語を何の苦もなく理解し使用できるようになる，言語を運用する際に，我 々は，過去に体験した有限の経験を越えることができるのである．チョムスキ 一によると，このことは，言語の構造と使用とを支配する抽象的な原理が人間 本来の生得的な特性であると考えることによってのみ可能となる ${ }^{(6)}$. 彼は，そ のような生得的な言語能力として, 言語データの予備的分析を行う知覚のシス テムと一定の文法のクラスを非常に狭く規定する図式とを想定する(7) .チョム スキーは，認知能力の枠内にある生得的特性を豊富に認め，学習をそのような 
生得的な構造の各々の項目を充填していくことと考えている．人間という種に 生物学的に決定されている生得的な認知構造のために，個々人の経験の多様性 にもかかわらず，成長の結果としての一様性が発現すると言うのである ${ }^{(8)}$. 以 上のような哲学を背景とするチョムスキーは，次のようなクワイン批判を表明 している.

クワインは，『ことばと対象』において「言語的な反応に関する子供の初期 の学習は，その反応にふさわしい刺激との連合を通してその反応を社会の側か ら強化する(reinforce)ことに依存している」(9) という見解を示した. チョムス キーは，クワインの言語学習一般に関する一連の主張の根底には，〈学習は強 化に基づく〉という見解が一貫して見受けられると考える(10). 強化によって 学習を説明しょうとするクワインのやり方は，まさにスキナーの図式を踏襲す るものである(11)。言語学習において経験的データが果たす役割よりも, 生得 的要因が果たす役割を重視するチョムスキーは，経験的データを偏重するクワ インの立場には満足しない. チョムスキーは, 強化という方法が, 単に挨拶や 儀礼的な決まり文句の学習にのみ役立つものでしかなく，言語学習の実質的な 内容を考察する際には，強化という概念を無視することさえ可能であると言う のである(12)

以上のようなチョムスキーの見解は非常に説得力のあるものとなっている. クワイン自身も，スキナー的なオペラント強化による文の学習のプロセス〔す なわち，文を非言語的な刺激に直接条件づけることによって，文を全体として 学習するという方法了が単に一つの発端にすぎないことを認めている(13)。 こ の点に，オペラント行動によりすべてを説明しょうとしたスキナーとの相違が ある，クワインは，チョムスキー同様，文の学習に関する完璧な理論が構成不 可能であることを認めており(14)，単に，言語学習の初期の段階を理解する際 には，条件づけ，帰納，現物指示などの行動主義的概念が有効であることを強 調したにすぎない，彼が唱える「外面化された行動主義(externalized behaviorism)」(15) の立場は，「学習レディネス(learning-readiness)」に到達するため に必要とされる最少限の生得的なメカニズムを認め, 経験的な探求によってそ 
の構造を積極的に解明しようとするものである. 実際に，クワインは，次のよ うなチョムスキーの主張に完全に同意している(16) 。〔したがって,クワインの 経験主義は，生得的構造を，単に知識獲得のための手順とメカニズムだけに限 定するものではない.]

「明らかに，我々は，(次に示す）二つの経験的条件に適うようなやり方 で，生得的構造を特徵づけるよう努力しなければならない，第一に，データ に接するという与えられた条件に基づいて要請された文法が獲得されるとい う事実を説明するのに十分なほど豊かな構造を，生得的な特性として有機体 に帰属しなければならない，第二に，諸言語のよく知られている多様性と両 立しえないほど豊かな構造を，有機体に帰属してはならない.」(17)

チョムスキーは, 言語を心の生得的能力によって決定される認知能力の一般 的体系の中に位置づけ，一定の方針による経験的探究によって言語の生得的特 性を理解していくことを目指している(18)，クワインも，チョムスキーと同様， 「我々が同意できるのは，古典的合理主義の学説と古典的経験主義の学説とを， （それらに対して）より直接的に経験的なテストを行いうるように再構成する （あるいは，おそらく別のものと置き換える）べきこと，及びそれらの学説の 妥当性の決定において，可能な限り経験的証拠に集中すべきことである」(19) という見解を快く支持するであろう。

また，クワインは，次のようにも述べている.

「言語能力は生得的であるが，一方，その能力を発動させるところの言語 学習は，いかなる生得的な言語もまたテレパシーも存在しないので，人間の 行動とそれをとり囲む環境との間主観的に観察可能な諸特徽に依存する。言 語学者は, 少なくとも言語学者としては，行動主義者となる以外に選択の余 地はほとんどない，そして，ある種の行動主義者のように，言語学者は，生 得的な素質を重視するはずである.」(20)

クワインのこの陳述は, 彼の行動主義観を理解する上で非常に重要なものと 考えられる. この陳述からも推測されるように, クワインが支持する行動主義 のポイントは，おおよそ〈言語学習のプロセスにおいて，人は公的に観察可能 
な他人の行動を手がかりとして進んでゆくしかない〉ということである．それ ゆえ，このように考える行動主義者[あるいは，経験主義者]が一定の生得的 な要因を認めることは，何ら矛盾を引き起こすものではない．ある種の生得的 要素の存在が, 外面的に現れた行動の傾向性によって裏づけられる場合には, そのような生得的要素を仮定することが許されるのである．ホッブスやガッサ ンディ，あるいはロック等によって展開された経験主義は，外部世界にその起 源をもつ感覚を重視するものであったので，生得観念を許すことができなかっ た. ところが, トゥックやベンサムによって経験主義が外面化された，すなわ ち，【主観的な〕観念から〔間主観的で社会的な制度である〕言語へと視点が 転換されたことによって，経験主義に生得観念を認める余地が生じたのである (21)

チョムスキーは，このようなクワインの見解を「行動主義とそれにまつわる 諸々の装いのすべてをほとんど完全に放棄したもの」(22) とみなし，それが，言 語を〈条件反応によって連合された文と刺激との構成体〉として理解し，文の 学習のメカニズムを，(1)文と刺激との連合，(2)文と文との連合，(3)類推による 合成，という三つの手順によって説明する『ことばと対象』の立場とは明らか に両立しえないものであることを指摘している(23). チョムスキーが, クワイ ンのこれらの見解を両立しえないものと決めつける背後には，知識を形成する のに必要とされる生得的な構造を経験主義的に特定することと合理主義的に特 定することとがそれぞれまったく異なる帰結を生み出すという信念がある．こ こでチョムスキーが言うところの経験主義的アプローチとは，生得的構造とし てデータ処理, 習慣形成, 帰納などの受動的なメカニズムのみを認め, 内容に 関してはまったくの白紙状態を想定するものであり，合理主義的アプローチと は，内容をも規定する強力な（能動的な）力を生得的特性として心に帰属する ものである.

ところで, クワインが要求することは，単に「すべての基準を観察名辞 (observation terms)で表現する」(24)[以下，これを“要請R”と呼ぶ]ことに すぎない，この要求を受け入れると，我々が想定する様々な仮説は，最終的に 
外部世界の観察に基づいて理解されなければならないことになる.クワインは， このように考えて，ある議論においては言語行動を手がかりとした．クワイン の言語学習の説明はスキナーの図式に則っているが，ここで注意しなければな らないことは，既に述べたように，クワインがオペラント行動による言語学習 の説明を，その初期の段階のみに適用可能なものとみなし，さらに，条件反応 のメカニズムによっては言語学習のすべてのプロセスを説明することができな いと考えている点である．実際に，彼は，子供が一定の段階に達してしまえば， それ以後の言語学習はオペラント行動に依存しなくなるという趣旨の発言をし ている(25).それゆえ，クワインをスキナーと同類の〈行動主義者〉という枠組 で捉えることは適切なことではない.

行動主義の考え方は上述の要請 $\mathrm{R}$ を満たすものであるので，クワインがそれ を妥当と思われる範囲内で採用するのは当然のことと思われる. とは言っても， クワインは，条件反応という心理学的な図式に固執する行動主義を斥けている (26)。彼は，人間の言語学習が観察可能な用語で表現可能な条件反応の図式に よっては説明できないことを理解していたからこそ, 観察文〔より適切には, 場面文了以外の文の翻訳が不確定的であることを主張したのである。一方，千 ヨムスキーが想定する生得的な言語能力に関する仮説であっても, それが要請 $\mathrm{R}$ を満たすものである限り，クワインはその仮説を認めるであろう(27).クワ インにとっては，チョムスキーが言うところの経験主義的アプローチと合理主 義的アプローチとの区別は問題とはならない．クワインが固執するのは，あく

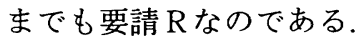

外面化された経験主義の立場をとるクワインは，人間に賦与されている生得 的な要素の仮定を最少限に押さえようとし，考察を始めるに際して，とりあえ ず知識を習得するための手順とメカニズムのみを生得的なものと考えた。 それ に対して，チョムスキーは，合理主義的な立場から，知識体系の一般的図式は 心の素質として生得的に決定されているものと考える。このように本質的に異 なる出発点に立ちながら，心に賦与された生得的構造の具体的な指摘において は，両者が非常に接近しているように思われるのはなぜであろうか．以下では， 
この点について若干考えてみたい.

クワインは，言語学習のプロセスを「主体が行う社会的なレベルでの用語法 に関する implicit な帰納」(28) と考えた.〔それゆえ，そのような観察されたデ 一タの集積と一般的な理論との間に経験的なゆるみが生じることになる.」一 方，チョムスキーは，帰納によっては，わずかなデータの人力により無限の文 を生成するという我々の心のメカニズムの発達を説明できないと考え, 合理主 義的な説明方法を採用した。 そのような複雑な言語学習を説明するためには， 多くの生得的な要素を想定しなければならないと言うのである.しかしながら， 彼は，与えられた言語的データと矛盾するほど豊かな構造を，生得的なものと して人間の心に帰属してはならないとも考えている(29)。そこで，彼は，アブ ダクションという推論形式により心の生得的な構造に関する仮説を立て，それ が多くの反証に耐えうるものであれば，その仮説は妥当なものと考えられると した.けれども，チョムスキーは，反証可能性をその基準としたことにより， 結果として, 生得的とみなされる構造の範囲を狭めていかなければならないこ とになってしまった。 実際に, チョムスキーは, Aspects of the Theory of Syntax においては，生得的な要素を基底 (base) の構造の大部分と非文体 的変形(non-stylistic transformations)の全体と考えていたが，その後は，ご く少数の原理〔それも反証に耐えうることが必ずしも十分に証明されていない ような原理了，たとえば，構造依存 (structure-dependence) の原理，下接性 (subjacency)の原理などだけを普遍文法として指摘している(30).一方，クワ インは，先述の要請 $\mathrm{R}$ を満たすような議論の展開を要求するので，チョムスキ 一が示している普遍文法が要請 $\mathrm{R}$ を満たす形で十分に確証される，換言すれば， 公的に観察されうる言語行動の傾向性と突き合わせてテスト可能である場合に 限り，それを認めようとするのである.

クワインとチョムスキーは, 実は, どちらも〈問題となっている仮説が経験 的に検証されうる〉という基準(31) に則って議論を進めているので，生得的な 特性に対して異なるアプローチをとりながらも，彼らがそれぞれのやり方でそ の正当性を証明した仮説のうちに共通項が存在するのである. 外面化された経 
験主義を，上述のような基準に従うものとして理解するならば，そのような経 験主義の枠組の中で, クワインは（古典的な）経験主義的方法を採用し，他方， チョムスキーは合理主義的方法を採用しているとみることができよう(32).

\section{2 約束手形としての行動主義}

チョムスキーが指摘しているように(33)，クワインは，「すべての基準を観察 名辞で表現する」という要請 Rが人間の心に賦与された生得的な構造について の考察に適用されるときには，それらの構造が「観察可能な行動の傾向性を表 す名辞に言い換えられうる」(34) のでなければならないと考えている.つまり， 人間の心的メカニズムについての仮説は, それがどんなものであろうとも，行 動の傾向性によって理解できるものでなければ要請 Rを満たしていないと言 うのである. 心的活動を理解しょうとするときに依拠することができる方法と しては，主として内省と行動の観察とを挙げることができる. 内省が客観的に 観察可能な方法でないことは明らかであるので，クワインは，〔言語行動をも 含む]行動の観察が心的活動を探究する際に非常に有効な手がかりとなると考 えたのである.

また，クワインが『ことばと対象』のII 章において明らかにしょうとしたこ とは，客観的に観察可能なデータのみを手がかりとして言語についてどれだけ のことを理解できるかということである．我々が客観的なデータのみに基づい てある人が現在習得している言語がどのようなものであるかを知ろうとすれば, 我々が利用できるものはその人の現在の発話の傾向性しかない. それゆえ，ク ワインは, ある人の現在の言語を, 現在与えられている刺激に対して言語的に 反応するその人の現在の傾向性を通して理解しょうとしたのである. 一方, 行 動主義者は, 内省的な方法に頼る意識内容の分析ではなく, 客観的に観察可能 な物理的刺激とそれに対する有機体の反応とによって行動を因果的に捉えよう とした. クワインと行動主義者は，いずれも自らの理論が科学的なものとなる ことを目指したので，その基盤に客観的に観察可能なデータを据えたのであり， この点にクワインと行動主義者の共通点を見てとることができる.ところが， 
行動主義者がそのような客観的に観察可能なデータに基づいて人間のあらゆる 行動を説明することを目標とした〔このような企てが無謀なものであることは すぐに判明した」のに対して，クワインの目標は，あくまでも客観的に観察可 能なデータに基づいて言語をどの程度理解できるかを見極めることであった． こうして，クワインは，言語においては経験的な刺激の場面と関連ゔけて理解 可能な領域がごくわずかであることを突き止めたのである(35). この結果は, 皮肉にも行動主義の挫折によって明らかになったことと一致している.

クワインと行動主義者とは，どちらも科学的な理論の構築を目指していたの で，その結果として類似した方法論を採用することになったが，両者が明らか にしょうとしていた事柄は，まったく異なっている，それゆえ，クワインをワ トソン的な強い行動主義者とみなし，クワインの哲学は, 強い行動主義と同様, 失敗に終わる運命にあると決めつけるのは早計であろう.

ところで，このように行動的基準を重視するクワインも，それが心そのもの の解明ではないことは十分に理解していた．クワインによると，傾向性という 概念は一般に，その実態がよくわかっていない事柄について語るための一時的 な便法として導入されるものにすぎない(36)．〈行動の傾向性〉という概念に依 拠する考察は，心の神経生理学的なメカニズムが解明されるまでの約束手形と して仮払いされているものでしかないのである，このことは，可溶性という巨 視的な概念が，物質の微視的な構造が解明されるまでの間，科学的な考察にお いて暫定的に使用されていたという状況と同様である.クワインは，心が科学 的に神経生理学のレベルにおいて解明されるまでは，客観的に観察可能な〈行 動の傾向性〉を頼りにして心にアプローチするしかないと考えている.

また, クワインは, 心についての神経生理学的な解明を, 最も深い(deepest) レベルに達した説明と考えている(37)。つまり，心についての説明は，(1)心的 な用語による説明，(2)行動的な用語による説明，(3)神経生理学的な用語による 説明，という順に深められる，換言すれば，心についての探究は，まず(1)が(2) に，そして最終的には(2)が(3)に還元されるべきだと言うのである(38). クワイ ンは，次のように述べている. 
「我々が生理学的な用語で言語活動を生理学的に説明することを現実のも のとして望みうるまでは，実際に機能するレベルは，第二のレベル，すなわ ち，外に現れた行動の傾向性というレベルなのである. $ل^{(39)}$

したがって, クワインは, 現在の科学の発展状況の下では, メンタリスティ ックな概念が行動的な概念によって置き換えられることのみを要求する.クワ インによれば，喜びや不安や痛みというような心的な用語でさえ，間主観的に 探知可能な身体の状態や行動を参照することによって学習されるのであるから， 心的な用語を身体の状態〔これは最終的には生理学的に記述される〕を指示す るものとして理解することは，まさに「心的な用語をそれが初めにあったとこ ろへ戻すこと」(40) なのである.

最後に，本論文の考察によって明らかになったことをまとめておく．クワイ ンが主張する行動主義のポイントは，おおよそ次の二点に要約される.

（1）行動主義の手法は，「すべての基準を観察名辞で表現する」という（強 い）経験主義の要請を満たすものとして，ある種の心的活動の説明に対し てのみ適用されるのであり，それによってあらゆる心的活動を説明するこ とが可能なわけではない.

（2）行動主義の手法は，メンタリスティックな概念を観察可能なやり方で理 解するための暫定的な方法にすぎず，心の最終的な解明は神経生理学に委称ら れる。

注

(1) B. Magee, Men of Ideas, Oxford Univ. Press (1978), p.147.

(2) E. g. N. Chomsky, Language and Mind, enlarged ed., Harcourt Brace Jovanovich, Inc. (1972), p. ix.

(3) Cf. N. Chomsky, Reflections on Language, Temple Smith (1976), pp. 1617.

(4) Ibid., p. 17.

(5) Ibid., p. 20.

(6) Cf. ibid., pp. $4-5$.

知識と信念の獲得に関する古典的な経験主義の説明は, 連合, 習慣, 形成など 
の原理を仮定することによって学習が進められる過程に目を向けたものであるが， チョムスキーによれば，このような学習理論では，知識や言語の無限的な拡大を 説明することはできない，彼は，成長した人間の知的構成の中には生得的に賦与 されていた認知構造に基づいて発達したものが豊富に含まれており，学習理論は そのような学習される内容を研究するものでなければならないと考えるのである. [Ibid., pp. 159-160. ]

( 7 ) Ibid., p. 12.

( 8 ) Ibid., pp. 39-40.

(9) W. V. Quine, Word \& Object, The M. I. T. Press (1979), p. 82.

(10) N. Chomsky, 'Quine's Empirical Assumptions', in D. Davidson and J. Hintikka (eds.), Words and Objections, revised ed., Reidel (1975), p. 55.

(11) Cf. W. V. Quine, Word \& Object, pp. 80-81.

N. Chomsky, 'Quine's Empirical Assumptions', p.56.

(12) Ibid., p. 56.

(13) W. V. Quine, Word \& Object, p. 82.

W. V. Quine, 'Reply to Chomsky', in D. Davidson and J. Hintikka (eds.), op. cit., p. 305.

W. V. Quine, 'Linguistics and Philosophy', in his The Ways of Paradox and other essays, revised and enlarged ed., Harvard Univ. Press (1976), pp. $57-58$.

(14) W. V. Quine, 'Reply to Chomsky', p. 305.

この箇所で, クワインは, 自分がこのことを以前から理解していたかのように 語っている.

(15) W. V. Quine, 'Linguistics and Philosophy', p.58.

(16) Ibid., p. 56.

(17) N. Chomsky, 'Linguistics and Philosophy', in his Language and Mind, p.170.

(18) N. Chomsky, Reflections on Language, p.123.

(19) Ibid., p.127.

(20) W. V. Quine, 'Reply to Chomsky', p. 306.

(21) Cf. ibid., p.306.

(22) N. Chomsky, Reflections on Language, p.200.

(23) Ibid., pp.199-201.

(24) W. V. Quine, 'Linguistics and Philosophy', p.58.

観察名辞とは,「直示によって教えられるもしくは教えられうるような名辞, したがって，個々の特定の事例に適用するに際して間主観的にチェックすること 
が可能な名辞」〔ibid., p.58〕を意味する.

(25) W. V. Quine, Word \& Object, p. 82.

(26) W. V. Quine, 'Linguistics and Philosophy', p.57.

(27) Cf. ibid., p. 57.

(28) W. V. Quine, Word \& Object, p. 125.

(29) N. Chomsky, 'Linguistics and Philosophy', p. 170.

(30) E. g. N. Chomsky, Reflections on Language, chap. 3 .

（31）この基準は，先ほど示した要請 $\mathrm{R}$ とは異なる. クワインが要求する要請 $\mathrm{R}$ は, この基準よりさらに強い制約を課すものである.

（32） A. Georgekよると，チョムスキーとクワインは，(1)より所とするデータ，(2) 何らかの生得的なメカニズムの要請; (3)最も進んだレベルの説明としての神経生 理学的な説明の支持，という点において一致しており，彼らの相違は，具体的な アプローチにおける戦略の相違に限定される.

[Cf. A. George, 'Whence and Whither the Debate between Quine and Chomsky ?', The Journal of Philosophy, vol. 83 (1986), p. 499. ]

(33) N. Chomsky, Reflections on Language, p. 249.

(34) W. V. Quine, 'Linguistics and Philosophy', p. 58.

（35）クワインによれば，「刺激の場面という独立した証拠に基づいて翻訳可能な」 〔W. V. Quine, Word \& Object, p.72.〕文は，場面文だけである.〔Cf. ibid., pp. 47, 71. ]

(36) W. V. Quine, 'Necessary Truth', in his The Ways of Paradox and other essays, p. 72.

(37) W. V. Quine, 'Mind and Verbàl Dispositions', in S. Guttenplan (ed.), Mind and Language, Clarendon Press (1975), p. 94.

(38) Ibid., p. 94.

後に，クワインは，自分の還元主義がく神経生理学の全貌が解明されても，タ イプとしての心的な用語がタイプとしての神経生理学の用語に翻訳可能であるわ けではない〉という，いわゆる非法則的な一元論 (anomalous monism) を主張 するものであることを明言している.

Cf. W. V. Quine, Quiddities, Harvard Univ. Press (1987), p. 133.

W. V. Quine, Pursuit of Truth, Harvard Univ: Press (1990), p. 71.

(39) W. V. Quine, 'Mind and Verbal Dispositions', p. 95.

(40) W. V. Quine, 'States of Mind', The Journal of Philosophy, vol. 82(1985), p.6.

(科学哲学) 